\title{
From flexibility to specificity: practical lessons from comparing materiality in sustainability reports of the world's largest financial institutions
}

\author{
Liad Ortar \\ The College of Law and Business, \\ 26 Ben-Gurion St., Ramat-Gan, Israel \\ Email: Liad.ortar@gmail.com
}

\begin{abstract}
Materiality' is a basic term used most frequently at the growing practices and discourses of sustainability and corporate social responsibility (CSR), and is the focus of this research. It is a term that depicts the prioritisation process for information disclosure. The term is rooted in the financial accounting profession and just recently embraced by sustainability reporting professionals and incorporated in its guidelines and methodologies. In accounting, it directs the accountant to include in the periodic report any performance indicator that might influence the value or financial outcome of the company. In sustainability reporting, materiality entails a different and a more stakeholder's oriented process. In this article, I present a historical overview of the term 'materiality' and examine its current functional value in sustainability reporting. The examination is based on grounded theory and an analysis of a sample of non-financial reporting practices with regard to their actual use and presentation of materiality.
\end{abstract}

Keywords: corporate social responsibility; CSR; materiality; sustainability reporting; financial sector; banks.

Reference to this paper should be made as follows: Ortar, L. (2016) 'From flexibility to specificity: practical lessons from comparing materiality in sustainability reports of the world's largest financial institutions', Int. J. Corporate Strategy and Social Responsibility, Vol. 1, No. 1, pp.44-64.

Biographical notes: Liad Ortar is the Manager of the Corporate Social Responsibility Institute (CSRI), College of Law and Business. He is a Lecturer at the Ben-Gurion University of the Negev.

This paper is a revised and expanded version of a paper entitled 'The obscurity of materiality in sustainability reporting' presented at the EBEN Annual Conference, Berlin, 12-14 June 2014.

\section{Introduction}

The public discourse and supporting documentation surrounding sustainability is expanding in its scope and diversity by the day. A Google search for sustainability would, at present, result in more than 74.4 million hits. Policy papers, books, and studies are published daily by consultancies, think tanks, academic researchers, global and local NGOs, and corporations (Banerjee, 2007; Wheeler et al., 2003; Reich, 1998; Higgins, 
2010). This body of research attempts to highlight a critical angle of sustainability, that of business disclosure and transparency of sustainability performances. To be even more precise, it relates to the preliminary decision-making process of what should or should not be exposed in a company's sustainability (non-financial) report. This is usually referred to as 'materiality,' which is the key term of this study.

Since the current discourse makes use of different terminologies, the main terms should be clarified. Sustainability, from a business perspective, is also known as corporate social responsibility (CSR) policy or corporate citizenship. These two major terms (sustainability and CSR), while similar, are not identical. Sustainability is a term first presented in 1987 in the Brundtland Report, also known as Our Common Future, which stated: "Humanity has the ability to make development sustainable to ensure that it meets the needs of the present without compromising the ability of future generations to meet their own needs" [United Nations, (1987), p.11]. Whilst CSR is defined by the European Union as follows:

"The Commission has defined CSR as the responsibility of enterprises for their
impact on society. ... [T] o fully meet their social responsibility, enterprises
should have in place a process to integrate social, environmental, ethical human
rights and consumer concerns into their business operations and core strategy in
close collaboration with their stakeholders." (European Commission)

A comparison of the two definitions provided above reveals that sustainability involves a broad public call for the current generation to take responsibility for the implications of its way of life and ever-growing consumption, thus promising future generations the same opportunities as it enjoys today. On the other hand, CSR is, by definition, oriented towards businesses or 'enterprises.' It is thus not a general concept, but rather a sectorial one.

Historically, the social concerns of business preceded the recent rise of sustainability. The origins of these social aspects can be traced back to the mid-twentieth century and the publication of The Social Responsibilities of the Businessman by Howard Bowen in 1953. Some would even point to an earlier beginning of social responsibility and relate it to Henry Ford's 1914 decision to double wages in the automobile industry to five dollars a day, thus expressing his responsibility and awareness of possible social risk (Corson et al., 1974).

In current corporate sustainability (CS) discourse, materiality is frequently used as a key phase in CS disclosure. Companies are expected to choose the most material issues in their sustainability challenges and then act and disclose accordingly. If an issue is identified as material, then it should be included and explained broadly in the sustainability report (SR) and in the company's allocation of resources and efforts. (It should be noted that SRs may also be termed 'social responsibility reports' or 'non-financial reports'. In this article, all non-financial disclosures will be termed SRs). If an issue is not material, then it is simply considered unimportant and calls for less attention on the organisational level and on the communicative level.

Many studies have used SRs as indicators of sustainability performance. However this approximation must be carefully examined, as SRs largely depend on how a company defines its activities and its own choice of what to report and what not to report (Murray, 2008). This is exactly what materiality is all about.

'Materiality' is a term rooted in the accounting profession. It entails many financial aspects of disclosure, including income tax allocation, treatment of renegotiation refunds, 
risk issues, and more (Bernstein, 1967), and directs the accountant to report any indicator that might influence the value of the company and thus the value of the shareholders' assets. In the case of some of the many and complex issues entailed in an SR, the financial reporting selection method will probably not be applicable, since not all longterm environmental and social effects can be inventoried annually and calculated to a single financial bottom line that appears on the balance sheet or in a profit and loss report.

This paper highlights the issue of materiality. First, it explores the history of the term and the current debate surrounding its meaning in SRs. Next, it examines 22 different SRs from the largest banks in the world to determine what and how they chose to report, in other words, their materiality approach. In the closing section, it continues the discussion based on the results of this examination and suggests further research directions.

\section{Research justification}

This study offers an important contribution to the evolving CS discourse and the frequently restructured guidelines and regulations (KPMG, 2013). It presents a coherent and critical perspective on a widely used term, demonstrating that in 'real life' there is significant variance in its interpretations and applications. It is hoped that this research and its conclusions will be perceived as a call for action for the creation of clearer SR guidelines and will ultimately result in reports that are more coherent and more easily compared to one another than those being issued today.

This research was conducted using an inductive approach, i.e., by examining actual perspectives on materiality as they appear in SRs from the banking sector. I decided to use test-case reports from the financial sector, since this sector is a very influential one. This sector may not directly manage power plants and large industrial facilities, but it does represent the financial backbone that supports and grants credit to the industrial sector as well as to governments, the real estate sector, and other dominant pieces of the economic puzzle.

\section{Research hypothesis}

On a personal note, the author of this paper served for the past ten years as a CSR consultant in Israel and, as part of his services, specialised in writing SRs. The author set the goals of this study after working with several financial institutions and is thus deeply familiar with the mindset of financial executives. This hypothesis of this study was based on this personal experience and the study aimed to verify (or refute) the personal observations of the author.

The hypothesis is that financial institutions make the utmost effort to appear as though they uphold the most severe set of reporting guidelines while maintaining the principle of discretion during the reporting process itself. As will be seen below, these two principles, transparency and discretion, contradict one another and the contradiction revolves precisely around the principle of materiality, especially according to the Global Reporting Initiative (GRI). 


\section{Background and context}

\subsection{Financial and non-financial reporting}

In any corporate operation, it is possible to differentiate between two major types of reporting: financial and non-financial. Financial reporting is conducted according to legal obligation as well as the operational need to report on financial achievements and the value of financial assets to the owners of the business, the shareholders. Thus, performance is assessed according to the goal of financial value maximisation (also known as single bottom line reporting), and this assessment will contribute to the decision of whether a certain issue will be included in the report or left out of it. Financial reports are written according to various conventions and have evolved over the past one hundred years so that they are comparable and reliable (Tschopp and Huefner, 2015). These policies and standards are called the Generally Accepted Accounting Principles (GAAP) (Murray, 2008). Financial reports may also include non-financial disclosures, as long as they have a direct and proven effect on the company's financial yearly valuation (Moir and Kennerley, 2006).

In the realm of non-financial reports, we take into account a very broad range of corporate communication 'products.' Any communication that is not financial by nature may be included. Such communications may include, for example, press releases, marketing brochures, internet site content, advertising campaigns, and so on. SR can also be included among these examples, although recent structuring efforts (e.g., reporting guidelines such as the GRI) have differentiated it from the rest. SRs provide a window into the social and environmental performance of a company and a way in which it can explain its approach and reasons for operating in a socially responsible manner (Murray, 2008).

SR is a practice that has a considerable history. It was traditionally part of accounting and financial reporting. The early term for it was 'social accounting' (accounting for non-financial aspects of a company's performance). An early comparative study by Ernst and Ernst (1978) defined the following categories in non-financial reporting: environment, energy, fair business practices, human resources, community involvement, products, and other social responsibilities disclosed. This typology is still widely used.

The summary declaration of the United Nations Conference on Sustainable Development in 2012 (the Rio+20) stated: "We acknowledge the importance of corporate sustainability reporting and encourage companies, where appropriate, especially publicly listed and large companies, to consider integrating sustainability information into their reporting cycle" (United Nations, 2012).

It is important to ask how and whether we can correlate SRs to the actual performance of social responsibility in business. Déjean and Oxibar (2003) conducted a comparative review that examined previous studies that compared non-financial reporting to variables such as reputational indices and objective measures such as the pollution performance ranking provided by the Council on Economic Priorities. None of the surveyed studies demonstrated a strong link between SRs and actual performance of social responsibility in business, and one of them even found a negative correlation between SRs and performance.

Although the findings clearly show weak correlations, transparency has now become established as a keystone in the architecture of CS. It is widely expected for a corporation that embraces CS to be obligated to commit itself to publicly communicating its 
sustainability performances and challenges. The tools with which a corporation works in order to organise and regulate its disclosures are called 'sustainability reporting guidelines'. These are issued by various organisations.

In general, we may categorise the guiding organisations as those whose main goal is shaping sustainability reporting and transparency, and those used as managerial/internal tools. In both cases, there are several internationally-accepted tools with complementarities and synergies (KPMG, 2013). The UN Global Compact principles and the OECD Guidelines for Multinational Enterprises fall into the category of managerial tools. The UN Global Compact is a strategic policy initiative for businesses committed to aligning their operations and strategies with ten universally accepted principles in the areas of human rights, labour, environment, and anti-corruption. By operating in alignment with these principles, business, as a primary driver of globalisation, can help ensure that markets, commerce, technology, and finance advance in ways that benefit economies and societies everywhere.

The OECD Guidelines for Multinational Enterprises are recommendations addressed by governments to multinational enterprises operating in or from adhering countries. They provide non-binding principles and standards for responsible business conduct in a global context consistent with applicable laws and internationally recognised standards. These guidelines provide a normative framework to help companies shape their sustainability vision and management approach and measure their impacts. ISO 26000 is a private management standard that provides guidance for organisations regarding the concept of CS and its definitions. It provides guidance on how businesses and organisations can operate in a socially responsible way. This means acting in an ethical and transparent way that contributes to the health and welfare of society.

Among the most commonly used reporting tools are the GRI and the SASB ${ }^{\mathrm{TM}}$. The GRI falls into the first category, sustainability reporting tools. It aims at providing organisations with disclosure items and metrics that align with the most important international normative frameworks, allowing them to benefit from each initiative's complementarities and strengths. The SASB, a similar, US-based initiative, was established to provide industry-based sustainability standards for the recognition and disclosure of material environmental, social, and government impacts by companies traded on US exchanges. It is a 501(c)3 non-profit that provides standards for use by publicly-listed corporations in the US in disclosing material sustainability issues for the benefit of investors and the public.

Since sustainability encompasses a wide range of issues, companies always face a fundamental dilemma in terms of what to report about and what information to relay when determining their SR content. The same dilemma (at the appearance of public criticism) was raised by stakeholders and the media, who suggested these reports were no more than public relations tricks, since they portray only the positive aspects of the corporation, and not the material influences. The question remains "How can/should a company decide what is materially important to report?" This is the issue of materiality, on which the present research is focused.

\subsection{The accounting origins of materiality}

In 1967, when Leopold Bernstein wrote his article "The Concept of Materiality", the global agenda was different than it is today. Climate change was only a vague scientific hypothesis and human rights issues such as child labour and sweat shops received little, if 
any, attention. Researchers in the USA were preoccupied with understanding materiality (Rose et al., 1970; Hicks, 1964; Rappaport, 1964) only from a financial perspective. A reading of Bernstein's 46-year-old article reveals many similarities between then and now in the evolving discourse and research that surrounds materiality. Bernstein defines the term simply as "part of the wisdom of life" [Bernstein, (1967), p.87], and asserts that there is no need to be concerned with what is not important. However, things have become much more complex since then.

In accounting practice, materiality is a central tool. It entails many financial aspects of disclosure, among them income tax allocation, treatment of renegotiation refunds, and risk issues (Bernstein, 1967). In the 1930s, the Securities and Exchange Commission (SEC) in the USA was concerned with the possibility that readers of financial statements would be swamped with unimportant information indiscriminately commingled with significant information (Bernstein, 1967). For this reason, a public commission published a clear definition of the term 'material', as follows: "The term material, when used to qualify a requirement for the furnishing of information as to any subject, limits the information required to those matters about which an average prudent investor ought reasonably to be informed" (Securities Act, 1933).

At the May 2005 IASB meeting in London, the International Accounting Standards Board framed materiality as a process that provides a threshold or cut-off point that determines what will be included in a financial statement and what will be left out. It elaborates as follows:

a [Materiality]. Relates not only to relevance, but also to faithful representation.

b Should be included in the converged framework as a screen or filter to determine whether information is sufficiently significant to influence the decisions of users in the context of the entity, rather than as a qualitative characteristic of decision useful financial information [Financial Accounting Standards Board, (2005), p.14].

'Materiality' therefore relates to the significance of transactions, balances, and errors contained in financial statements. It defines the threshold or cut-off point beyond which financial information becomes relevant to the decision-making needs of users. Information contained in financial statements must therefore be complete in all material respects in order for the statements to present a true and fair view of the affairs of the entity.

Various definitions of materiality and related guidance for financial reporting evolved over the years, as new interpretations of principles of materiality were adopted by standard setters, regulators, and international organisations (Murninghan, 2013). It is clear that in accounting practice, materiality is measured as an expected change/loss in net income expressed in accepted monetary terms. Any material indicator can be quantified as a monetary value added up in the yearly balance. The question is how and to what extent sustainable issues can be measured, if at all, especially taking into account that their effect might be long-term rather than annually-based.

\subsection{Materiality in the financial sector}

Banks have a tremendous impact on global and local financial affairs, as well as on world trade (Haldane et al., 2010). The question is what is, or what should be the impact of the financial sector on other global issues, such as global warming, human rights, corruption, 
fair trade, and sustainability reporting? And, accordingly, how should banks report on their sustainability performances?

The GRI added sector supplements to its guidelines. The first one published was for the financial sector: "Sustainability Reporting Guidelines \& Financial Services Sector Supplement" (or FSSS). In it, the GRI identified a list of material indicators that emphasise the monetary value of other performance indicators (PI). The FSSS also asks reporting banks for disclosure on their attitude and practice regarding environmental and social investment screening and preferences. The SASB launched a similar financial sector guide that is publicly published for multi-stakeholder consultations. The consultation process will result in a sustainability materiality list that may include indicators such as promoting the integration of environmental, social, and governance performance in capital markets and systematic risk management.

In the case of both the GRI and the SASB sectorial guidelines, it is clear that the material aspects of banks are those that relate to the environmental and social risks and ramifications of their financial activities. Although operational environmental measurements such as light bulb replacement and double-sided printing are not undervalued, these factors still do not have a significant social and/or environmental impact.

\section{Materiality in the accepted sustainability reporting guidelines}

Since SR is designated to answer the expectations of stakeholders, and since 'stakeholders' is an umbrella definition for various different audiences (groups of readers), each of which has a different set of expectations, different reporting guideline approaches have different emphases on materiality. Of the different existing approaches, I decided to examine three major reporting guidelines evaluated by Business for Social Responsibility (BSR), presented in the report "Navigating the Materiality Muddle" (Allison-Hope, 2013) and chosen as the most important ones. BSR is a global non-profit business network dedicated to sustainability. It works with a network of more than 250 of the world's most influential companies to inform and strengthen their sustainability efforts.

The report "Navigating the Materiality Muddle" (Ibid) explains that today there are three major sustainability reporting organisations: the International Integrated Reporting Council (IIRC), the SASB, and the GRI. The three diverge in their approaches towards materiality decision making, in accordance with the stakeholder groups toward which they orient their initiatives.

\subsection{The IIRC materiality approach}

In April 2013, the IIRC published a consultation draft of the International Framework. The draft was open for comments and the final version was published in December 2013. The consultation draft defines materiality as follows: "concise information that is material to assessing the organization's ability to create value in the short, medium and long term". 
The IIRC defines materiality as an issue that can substantively influence the assessments of the primary intended report users. It also refers to a material issue as one that substantively affects, or has the potential to substantively affect, the organisation's strategy, its business model, and one or more of the capitals it uses or affects in the short, medium, or long term. As to the defining process, the IIRC is focused on evaluating the effects of the issue on the capitals owned by or available to others. Thus, it also includes the value creation process. The materiality process is explained broadly in the guidelines themselves, but the focal point in the decision- making process is primarily an internal one that focuses on managerial skills and discretion without truly deliberating with the corporation's external stakeholders.

\subsection{The SASB materiality approach}

The US-based SASB is a non-profit organisation that assists publicly-listed corporations in the USA in disclosing material sustainability issues for the benefit of investors and the public. SASB standards are designed for disclosure in mandatory filings to the SEC, such as forms $10-\mathrm{K}$ and $20-\mathrm{F}$. As SASB is specifically directed towards adding sustainability PI to the regulated accounting disclosures, its approach to materiality is more authoritarian than that of the IIRC.

The SASB severely limits corporations' own prioritising by publishing its own guidelines, called the 'materiality map'. This is a road map that a corporation should use to determine its material sustainability issues. The SASB's materiality map presents the relative prioritisation of sustainability issues on an industry-by-industry basis, allowing users to compare and contrast the materiality of more than 40 issues across industries and sectors. Each sector's guidelines are published for public comments and consultations before they are finally accepted and published for use.

\subsection{The GRI materiality approach}

In May 2013, the GRI published a revised version of its sustainability reporting guidelines, the G4. These guidelines include two documents: a general one called "Reporting Principles and Standard Disclosures", and a second one, which provides a broader perspective and more guidance, called 'Implementation Manual'. Materiality is addressed in both documents with the following instructions:

\footnotetext{
"Material Aspects are those that reflect the organization's significant economic, environmental and social impacts; or that substantively influence the assessments and decisions of stakeholders. To determine if an aspect is material, qualitative analysis, quantitative assessment and discussion are needed." [GRI, (2013a), p.92]
}

In addition to the written explanations, the GRI also provides graphic guidance, which is called a materiality matrix. 
Figure 1 GRI, G4 Implementation Manual (2013b, p.12) (see online version for colours)

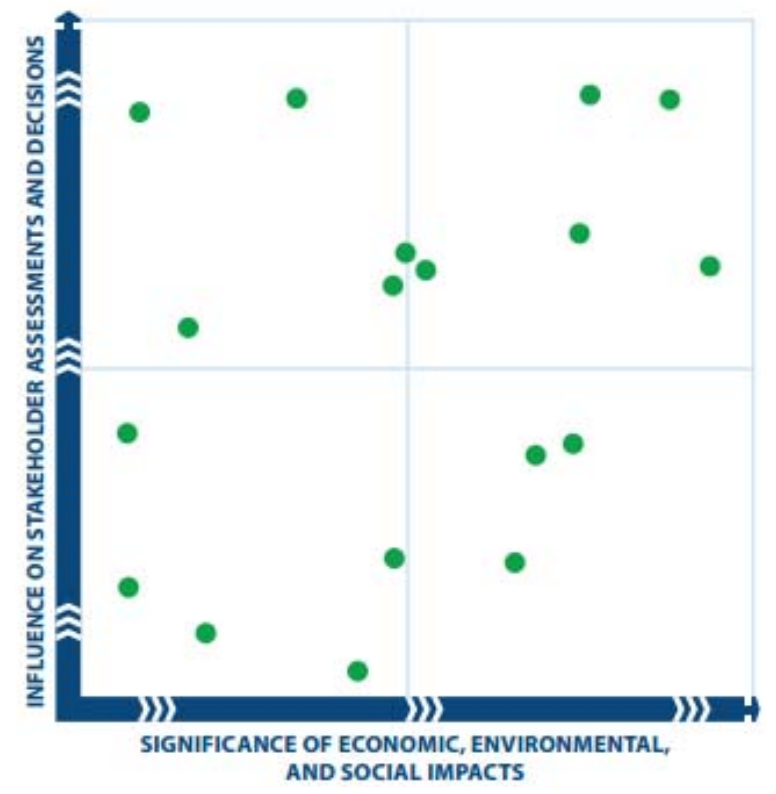

The GRI sets a base for a much broader and more collaborative process of materiality reporting, as it includes meeting points of different sustainability issues on two axes. According to the GRI, the variable values should stem from a dialogue among stakeholders. The horizontal axis represents the level of importance of the specific sustainability issue to the corporation's success, while the vertical one represents the importance of the selected issue to stakeholders.

The GRI externalises the materiality decision-making process, taking it outside of the organisation in a collaborative process between the organisation and its stakeholders. However, businesses are still expected to take responsibility for leading and managing the process. The result is that, de facto, material issues for reporting are still decided by the (corporate) reporters themselves, as they are the ones to decide who to invite to the consultations and how the consultations are to be conducted.

\subsection{Reporting guidelines: a comparative discussion}

One way to differentiate between approaches to materiality decision making is by relating to the process as either rule-based or principle-based (Murninghan, 2013). According to this typology, we can conclude that the GRI guidelines tend to be principle-based, e.g., they base the process on a stakeholders' management approach. The other two sets of guidelines, the SASB and the IIRC, can be categorised as rule-based because they leave less room for managerial manoeuvring in the process.

The difference between the three major approaches can also be described in a slightly different way, by understanding who the target audience of the report consists of, what timeline it represents, and the nature of the managerial process. Table 1 summarises this comparison. 
Table 1 Comparison of reporting guidelines

\begin{tabular}{llll}
\hline & Report target audience & Timeline & Managerial process \\
\hline IIRC & Investors & Long-term & Internal \\
SASB & Regulators & Medium- - long- term & Internal \\
GRI & Multiple audiences & Short-medium & $\begin{array}{l}\text { Demands external feedback from } \\
\text { stakeholders }\end{array}$ \\
\hline
\end{tabular}

This method of comparison reveals a lack of uniformity in the approaches. These are essentially three completely different approaches. The GRI's approach is collaborative, gaining insights through a process of engaging stakeholders. The others have paved the way to determining the importance of the different sustainability issues with very little room for change.

Why is there a need for uniformity in sustainability reporting? Uniformity in SRs in general and specifically in materiality decision making facilitates comparability and acts as a quality regulator. There is a need for a common frame of reference, without which uniformity of practice is impossible. Early research on materiality issues in accounting deduced that in the absence of materiality guidelines, considerations other than those intended by the legislature for the protection of the shareholder played a dominant role (Bernstein, 1967). As this research has shown, such is the current situation in nonfinancial reporting and the protection of stakeholders' interests.

\section{The research}

This study employs two complementary qualitative methodological approaches. The primary methodology is a textual analysis of descriptive paragraphs on materiality in the selected SRs. It is an adaption of grounded theory methodology as an inductive way of analysing the context in which materiality appears and exploring how it is being used (Conaway and Wardrope, 2010).

The textual examination was conducted solely by the author of this paper. This method may limit the validity of the findings to a certain degree, but since this is a preliminary qualitative study, future research should be conducted to further explore the issues at hand.

The two textual aspects examined were the materiality decision-making process as it is described in the reports, and the reported material issues themselves. In this context, the leading questions for comparison addressed how the companies described their prereporting decision-making process. Does the process focus on internal/organisational processes, or does it include external stakeholder expectations? After choosing the material issues, does the explained process tend to be 'guideline-oriented' (using an external materiality 'manual') or 'dialogue oriented'? Last, are there any changes in the material issues over time?

The secondary research approach is a thematic comparison between the selected SRs. The comparison was conducted using NVivo 8 (QSR International, 2014) content analysis software with the word similarity application. This process is used in order to explore recurring words and thematic relationship between reports (Conaway and Wardrope, 2010). 


\subsection{Research sample}

In this study, I surveyed 22 SRs from the five largest financial institutions in the world. The sources of the SRs were the banks' official internet sites, the GRI database, and CorporateRegister. The latter two are referral sites that direct readers to the bank internet site, where the PDF file is available for downloading.

The choice of appropriate banks for the research was based on several criteria:

- Size. The search began with the largest banks in the world and the list was gradually narrowed.

- Sustainability reporting tradition. Any bank selected must present a five-year continuum of reporting (2008-2012), i.e., must have published at least three reports during the years mentioned. It should be noted that each year's report summarises the bank's activities in the previous year, so that the 2008 report, for example, relates to activities that took place in 2007. The five-year period was decided upon in order to include pre-2008 crisis reports to determine whether the financial crisis had any impact on the reports.

The results are summarised in Table 2 .

Table 2 Reports sample

\begin{tabular}{llcccccc}
\hline Rank in size & Bank & Country & 2008 & 2009 & 2010 & 2011 & 2012 \\
\hline 1 & $\begin{array}{l}\text { Industrial and Commercial } \\
\text { Bank of China (ICBC) }\end{array}$ & China & $\mathrm{V}$ & $\mathrm{V}$ & $\mathrm{V}$ & $\mathrm{V}$ & $\mathrm{V}$ \\
& HSBC Holdings & $\mathrm{UK}$ & $\mathrm{V}$ & $\mathrm{V}$ & $\mathrm{V}$ & $\mathrm{V}$ & $\mathrm{V}$ \\
2 & Deutsche Bank & Germany & $\mathrm{X}$ & $\mathrm{V}$ & $\mathrm{V}$ & $\mathrm{V}$ & $\mathrm{V}$ \\
3 & Crédit Agricole Group & France & $\mathrm{X}$ & $\mathrm{X}$ & $\mathrm{X}$ & $\mathrm{X}$ & $\mathrm{X}$ \\
4 & BNP Paribas & France & $\mathrm{V}$ & $\mathrm{V}$ & $\mathrm{V}$ & $\mathrm{V}$ & $\mathrm{V}$ \\
5 & Mitsubishi UFJ Financial & Japan & $\mathrm{x}$ & $\mathrm{V}$ & $\mathrm{V}$ & $\mathrm{V}$ & $\mathrm{V}$ \\
6 & Group & & & & & & \\
\hline
\end{tabular}

Notes: $\mathrm{V}$ box - included

$\mathrm{X}$ box - not included

\section{Findings (1) - primary research methodology - contextual comparison}

The selected sample includes the world's five largest financial institutions: ICBC, HSBC Holdings, Deutsche Bank (DB), BNP Paribas, and Mitsubishi UFJ Financial Group. This section presents a bank-by-bank comparison.

\subsection{ICBC-China}

The Industrial and Commercial Bank was established in August 1988 and is headquartered in Fuzhou City, Fujian Province. It is one of the first joint-stock commercial banks approved by the State Council and the People's Bank of China. On February 5, 2007, it was listed on the Shanghai Stock Exchange (Stock Code: 601166) with a total registered capital of RMB10.786 billion (ICBC). 
The 2008 SR is available in Chinese only, with no reference to an English version. In the $2009 \mathrm{SR}$, there is no materiality analysis and no identification of material issues. From the opening remarks of the chairman, we can deduce that the most important issues are energy efficiency, financing products as a starting point, and the adoption of the Equator Principles (EPs). (The EPs form a risk management framework that was adopted by financial institutions for determining, assessing, and managing environmental and social risk in projects, and are primarily intended to provide a minimum standard for due diligence to support responsible risk decision making.) In the $2010 \mathrm{SR}$, there is no materiality analysis and no identification of material issues. The report is very wideranging and covers all issues. Stakeholders' expectations appear at the beginning of the report, as a list: regulatory authorities, shareholders, customers, employees, partners, the environment, and resources and society.

In the 2011 SR, we find the names of actual global environmental NGOs, such as WWF and Friends of the Earth for the first time, in the chapter titled 'Dialog with NGOs' [ICBC, (2011), p.109]. Nevertheless, it is a very short chapter. There is still no materiality analysis, but again there is a long table very similar to the one presented in the report for the previous year. The 2012 SR states: "In 2012, the Bank continued to maintain multi-level dialogues with domestic and overseas NGOs" [ICBC, (2012), p.121]. A very short paragraph that mentions several concrete interactions follows. There is no materiality matrix or analysis of any kind. The general expectations of stakeholder groups are again provided in a table, exactly as in the previous report.

ICBC is the largest bank in the world. Its scope of operation is huge, covering the entire globe. It is evident in the report that the bank embraces advanced approaches for environmental and social risk management, mainly the EPs. As for stakeholder engagement and collaboratively deciding upon material suitability issues, this aspect is absent from the report and although in 2010 stakeholder expectations are outlined, it is unclear how these insights were raised and who the representatives of the general stakeholder groups are. Furthermore, the issues mentioned have remained unchanged over the last several years, with only minor differences in wording appearing in the report.

\subsection{HSBC Holdings plc $-U K$}

HSBC Holdings plc was founded in 1865 to finance trade between Asia and the West. Today, HSBC is one of the world's largest banking and financial service organisations, serving some 55 million customers. Headquartered in London, HSBC operates through long-established businesses and an international network of some 6,600 offices in 80 countries and territories.

From the sequence of reports, it is clear that HSBC underwent a major change in its attitude concerning sustainability. The commitment might have remained unchanged, but disclosure from 2008 to 2010 on stakeholders' engagement process and materiality decision making was much more precise, specific, and business-goal oriented than it had been in the past. The 2008 report states: "In response to feedback on previous years' reports, we continue to focus on the non-financial issues considered material to our business" [HSBC, (2008), p.1]. The material issues as described in this report are the global economy, customer relations, retaining and developing top talent, climate change, future in social opportunity, and sustainable use of natural resources.

The 2009 report states: 


\begin{abstract}
"In response to stakeholder feedback, this report focuses on HSBC's sustainability priorities. These priorities emerge in a number of ways: they may be a key to our overall business strategy; or they are a particular concern to our stakeholders and are therefore likely to have a financial or social impact on the bank and our customers; or they are issues raised through our own research." [HSBC, (2009), p.3]
\end{abstract}

The six priorities identified for 2009 and 2010 were: financing a low-carbon economy, risk management in lending and other financial services; valuing employees; customer trust; investing in communities; and keeping the bank's own house in order in relation to operational environmental management and the supply chain. The discussion of these issues ends with the statement "The theme of climate change runs through all of these priorities" [HSBC, (2009), p.3].

The 2011 SR declares: "We have identified six areas which, taken together, make our business sustainable" [HSBC, (2011), p.6]. However, deep examinations of the pages that follow reveal that there is actually no explicit identification of these material issues. After 2011, it is noticeable that the bank took several steps backwards and became less willing to commit publicly on specific issues. None of the surveyed reports contained any kind of materiality analysis, so it is unclear what issues, if any, were raised by stakeholders and not addressed in the bank's operations. In the 2012 report, the concept of stakeholders' engagement was reduced to a short section titled "Engaging with Governments and Regulators" [HSBC, (2012), p.7].

\title{
$7.3 D B-$ Germany
}

DB was founded in Berlin in 1870 to support the internationalisation of business and to promote and facilitate trade relations between Germany, other European countries, and overseas markets. DB has developed into a leading global provider of financial services, operating 2,984 branches with 98,000 employees globally (DB).

DB did not publish an SR in 2008. The 2009 SR does not include any kind of external procedure or dialogue on material issues. This report begins with a description of five areas of activity: sustainability, corporate volunteering, social investments, art education, and music education. These areas are very broad and cover a wide range of activities. In the 2010 SR, for the first time, we see a detailed paragraph that explains the bank's attitude towards the added value of a dialogical process:
"We conduct a regular dialog with our stakeholder groups in order to understand what special expectations they place on us as a financial institution and to explain our positions. This provides us with important impetus for more sustainability in our business activities. We also learn about new ideas and concepts for practice and thus promote acceptance for our activities." [Deutsche Bank, (2010), p.34]

According to the materiality matrix presented in the report, the material issues are: sustainable products, sustainable guidelines, consumer protection, reputational risk management, remuneration, and stakeholder dialogue.

It seems that DB's materiality presentation peaked in 2010. In that year, there was a well-explained dialogical process with justification as to its importance in materiality decision making. We also saw a materiality matrix that was prepared in accordance with the GRI G3 guidelines. This has not been seen again in later reports, nor did the material issues retain their status in these reports. In 2011 and 2012, the bank presented a unique 
initiative on pressing issues such as cluster munitions and microfinance, but the decisionmaking process that precedes them remained obscure.

\subsection{BNP Paribas - France}

With a presence in 78 countries and nearly 190,000 employees, including more than 145,000 in Europe, BNP Paribas is a leading bank in the euro zone and a first-class player on a global scale.

The 2008 SR does not include any description of stakeholder engagement. The 2009 report presents a long list of 'communication initiatives' between the bank and its various stakeholders [BNP Paribas, (2008), pp.31-32]. In most items, the initiatives are one-sided and there is no explanation regarding the input received from the engaged groups (e.g., tools such as surveys, newsletters, and so on), and no identification of material issues. In 2010, the list is identical to the one from the previous year. The difference is that the title is now: "Organized Dialogue with Stakeholders" [BNP Paribas, (2010), p.19]. The 2011 report begins by presenting highlighted issues and the different steps implemented in each area. These issues can be referred to as material, and include 'combating climate change' [BNP Paribas, (2010), p.14] and 'combating exclusion' [BNP Paribas, (2010), p.16], in the 2012 SR, there is no constructive explanation of stakeholders' engagement process. There are some initiatives, such as the Palm Oil Roundtable, but there is a lack of clarity regarding issues brought up by external players. The SR does begin with a broad perspective on important issues, including highlights: financing the economy in an ethical manner, combating exclusion, promoting education and culture, pursuing a committed and fair human resources policy, and combating climate change.

BNP Paribas is the fourth largest bank in the world. Its commitment to sustainability initiatives is very clear from its report. External sustainability ratings and commitments such as the FTSE4Good, the Dow Jones Sustainability Index, the Global Compact, and many others are all embraced by the bank as proof of its commitment. Nevertheless, the surfeit of stories presented in the report makes it difficult to trace the facts, and the lack of any kind of materiality analysis makes it even more difficult to understand. To put it simply, comparison to other reports is impossible and external stakeholders' expectations are unclear.

\subsection{Mitsubishi UFJ Financial Group - Japan}

Mitsubishi UFJ Financial Group, Inc. is a Japanese bank holding/financial services company headquartered in Chiyoda, Tokyo, Japan. As of March 2011, it held assets of approximately US\$2.5 trillion. It is one of the main companies of the Mitsubishi Group (MUFG). Mitsubishi UFJ is the largest bank in Japan.

The Mitsubishi UFJ Financial Group, Inc. did not publish an SR in 2008. The 2009 SR begins by identifying material issues as perceived by the bank:

"We recognize that the very existence of the MUFG Group is sustained by society as a whole and that we therefore have a duty to consider the key issues facing society. Thus, we have adopted 'Addressing Global Environmental Issues' and 'Nurturing Society's Next Generation' as the two priority themes for the entire Group." [Mitsubishi UFJ, (2009), p.5]

The themes that appear in the SR are 
1 Global environmental issues such as global warming and climate change.

2 Nurturing society's next generation, which includes addressing issues such as global environmental problems and poverty on a global scale, as well as domestic problems in Japan, such as slow population growth, the ageing of the population, and local or regional issues.

3 Key global issues.

4 Poverty and related issues, for example, hunger, labour, human rights, and education.

The 2010 SR was published in Japanese only. The 2011 report was published following the major earthquake that struck the country and the issue is placed at the beginning of the report and addressed as a material one: "Response to the Great East Japan Earthquake" [Mitsubishi UFJ, (2011), p.4]. Following this report, the identical themes mentioned in the previous report appear.

From its first report, Mitsubishi UFJ clearly articulates what its material issues are. However, the issues remain largely unchanged during the five-year period of reporting. The only change is that in 2011, the catastrophic earthquake is an item that receives attention and is placed at the beginning of the report. The decision-making process is mainly an internal one, with no external arguments presented other than the stakeholders' panel in 2011.

\section{Findings (2) - secondary research methodology - thematic analysis}

This section presents the main findings of the analysis of the 22 reports surveyed using Nvivo software. The results (Figure 1) show that when comparing annual reports from the same bank (HSBC), there is a clear thematic connection between the reports. Figure 1 is the result of comparing HSBC SRs from five consecutive years (2007-2011). It is clear that the five reports correlate with each other and thus there is a high level of word similarity between them.

Figure 1 Comparison between HSBC Reports (see online version for colours)

HSBC Sustainability Reports (2007-2011) Word Similarity

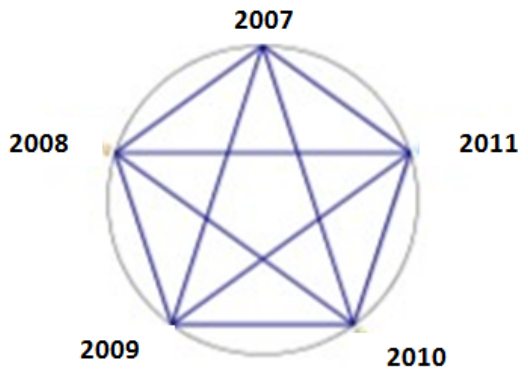

A second comparison was conducted, again to reveal similarities between the reports. This comparison was conducted between the five selected reporting banks for their 
reports published in 2011. Figure 2 reveals that there is no single word-resemblance link established in any of the potential 10 linking lines. The reports are very different from each other.

Figure 2 Comparison between banks (see online version for colours)

\section{Word Similarity Analysis - for the 5 reports published in 2011 by the different banks}

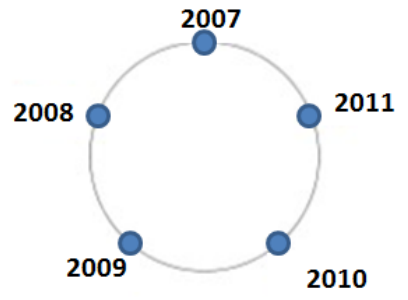

\section{Discussion}

The main idea behind SRs is that they should provide stakeholders with comparable, simple, and clear information on a corporation's sustainability performance and commitments. The findings of this study reveal that this is currently not the case. The examined reports were found to be lengthy and it was extremely difficult to conduct a comparative analysis between them.

Comparing two consecutive annual SRs either reveal no differences at all or tremendous differences between them. In either case, such comparison raises questions regarding what took place during the time gap between the reports. In the case of evident dissimilarity, the question of why the reporting institution begins each report from the beginning arises. On the other hand, in cases of clear and close similarity, the question of why the reporting institution has not done anything significant in the period between the two reports arises.

The goal of this research was to investigate how financial institutions relate to materiality in their reports and disclosures. All the banks examined presented very strong declarations as to their commitments to sustainability and obligation to important global initiatives. However, their attitude toward the disclosure of materiality issues is not in line with these declarations, and in most cases such disclosure is absent from the reports. Following are the main insights from the findings:

- All of the banks examined present an internal decision-making process in order to decide upon their material sustainability issues. External expectations deduced from any kind of stakeholders' dialogue are rarely presented and play no concrete role in the reporting process.

- The banks adopt global CSR initiatives such as the global compact and the EPs. However, the adoption of these initiatives has no influence on the reports with regard to materiality disclosures. 
- Of the 22 reports surveyed, only one presented a materiality matrix as defined and explained in the GRI G3 guidelines.

- There is currently no widely accepted reference for materiality decision- making procedures, nor is there an accepted glossary of sustainability term and issues. The GRI PI could be considered such a resource. However, the suggested material issues as they appear in the reports examined are of a much broader scope not fully compatible with the GRI's PIs.

- As Figure 2 demonstrates, the reports examined are not at all similar to one another, and thus it is very difficult to compare them. Although the latest SRs do include a GRI index that can be used as a reporting navigation tool, the task of comparing the reports remains extremely challenging.

My hypothesis in this research was that since the financial sector is regarded as a discreet one, not freely disclosing internal processes, its materiality approach would, on the one hand, answer the globally excepted reporting requirements in the most comprehensive manner, but on the other, maintain minimal external intervention and dialogue with stakeholders. According to the findings, I can conclude that the hypothesis has been proven to be correct. The SRs are at a minimal level as far as external stakeholders' engagement is concerned, keeping voluntary disclosure only at a bare minimum.

Today, a global increase in the number of policy and regulation initiatives for non-financial reporting is apparent. In light of this increase, reporting organisations (corporations) are voicing their concerns regarding the various (and sometime conflicting) frameworks they are expected to use or are obliged to comply with and thus seeking the alignment and harmonisation of the frameworks. As report audiences differ from one another and are expected to grow (especially among the investing community), the discussion on the credibility of sustainability data will, in all likelihood, continue to increase (KPMG, 2013).

As CS reporting becomes increasingly regulated and less voluntary, it is crucially important for leading global organisations that endorse sustainability reporting to decide upon a global set of accepted sector PI. The current situation in which materiality is used as a flexible principle, defined and redefined by the reporting institutions themselves, will probably not result in the formulation of reporting guidance and tools that are in harmony with external expectations and global consolidations.

\section{Research contribution and the way forward}

This study opens up a wide range of future research directions. Some of these directions are already being addressed. See, for example Jones et al. (2015), who examined the use of materiality in the UK's top ten retailers. Their research found significant variations in the extent to which the examined corporations are embracing materiality. It also found no sector-specific material issues that appear consistently throughout the reports.

It may be very relevant to look at additional sectors as well and examine their approaches towards sustainability reporting. It may also be productive to examine mechanisms and agents that can regulate non-financial reporting and create a true triple bottom line reporting scheme. Other directions, such as examining materiality changes 
over a period of time and creating a country materiality matrix and a global one, could also contribute to this yet unexplored academic area.

\section{Acknowledgements}

The author would like to deeply thank Dr. Yotam Lurie from the Guilford Glazer Faculty of Business Management at the Ben-Gurion University of the Negev for his ongoing dedicated support and advice, academically and personally. The author would also like to thank Prof. Moshe Cohen-Eliya, President of the College of Law and Business, for giving him the opportunity to make a difference.

\section{References}

Allison-Hope, D. (2013) 'Navigating the materiality muddle', BSR (Business for Social Responsibility), 13 August [online] http://www.bsr.org/en/our-insights/bsr-insightarticle/navigating-the-materiality-muddle (accessed 20 September 2015).

Banerjee, B.S. (2007) Corporate Social Responsibility, Edward Elgar Publishing Limited, Cheltenham and Northampton.

Bernstein, A.L. (1967) 'The concept of materiality', The Accounting Review, Vol. 42, No. 1, pp.86-95.

BNP Paribas (2008) Report on Environmental and Social Responsibility [online] http://www.corporateregister.com/a10723/26772-09Su-5622120Y2166390240A-Gl.pdf (accessed 20 September 2015).

BNP Paribas (2010) Report on Environmental and Social Responsibility [online] http://www.corporateregister.com/a10723/39719-11Su-10525535A5395428960X-Gl.pdf (accessed 20 September 2015).

BNP Paribas [online] http://www.bnpparibas.com/en http://www.bsr.org/en/our-insights/bsrinsight-article/navigating-the-materiality-muddle (accessed 20 September 2015).

Bowen, H. (1953) Social Responsibilities of the Businessman, Harper, New York.

$B S R$ [online] http://www.bsr.org/en/ (accessed 20 September 2015).

Conaway, R.N. and Wardrope, W.J. (2010) 'Do their words really matter? Thematic analysis of US and Latin American CEO letters', Journal of Business Communication, Vol. 47, No. 2, pp.141-168.

Corporate Register [online] http://www.corporateregister.com/ (accessed 21 September 2015).

Corson, J.J., Steiner, G.A. and Meehan, R.C. (1974) Measuring Business's Social Performance: The Corporate Social Audit, Committee for Economic Development, New York.

Déjean, F. and Oxibar B. (2003) An Alternative Approach of Corporate Social Disclosure Analysis [online] https://halshs.archives-ouvertes.fr/halshs-00150581 (accessed 20 September 2015).

Deutsche Bank (2010) Corporate Social Responsibility Report [online] http://www.corporateregister.com/a10723/38747-11Su-7943135H1266174466I-Gl.pdf (accessed 18 September 2015).

Equator Principles [online] http://www.equator-principles.com/ (accessed 21 September 2015).

Ernst and Ernst (1978) Social Responsibility Disclosure: Survey of Fortune Annual Reports, Ernst and Ernst, Cleveland.

European Commission [online] Corporate Social Responsibility [online] http://ec.europa.eu/growth/industry/corporate-social-responsibility/ (accessed 20 September 2015). 
Financial Accounting Standards Board (2005) Board Meeting Handout: Conceptual Framework [online]

http://www.fasb.org/cs/BlobServer?blobcol=urldata\&blobtable=MungoBlobs\&blobkey=id\&bl obwhere $=1175818807953 \&$ blobheader=application\%2Fpdf (accessed 27 September 2015).

Global Reporting Initiative (2011) GRI and ISO 26000: How to Use the GRI Guidelines in Combination with ISO 26000 [online] https://www.globalreporting.org/resourcelibrary/HowTo-Use-the-GRI-Guidelines-In-Conjunction-With-ISO26000.pdf (accessed 20 September 2015).

Global Reporting Initiative (2013a) G4 Sustainability Reporting Guidelines, Reporting Principles and Standard Disclosures [online] https://www.globalreporting.org/resourcelibrary/GRIG4Part1-Reporting-Principles-and-Standard-Disclosures.pdf (accessed 20 September 2015).

Global Reporting Initiative (2013b) G4 Sustainability Reporting Guidelines, Implementation Manual [online] https://www.globalreporting.org/resourcelibrary/GRIG4-Part2Implementation-Manual.pdf (accessed 20 September 2015).

Global Reporting Initiative (n.d.) Sustainability Reporting Guidelines and Financial Services Sector Supplement [online] https://www.globalreporting.org/resourcelibrary/G3-EnglishFinancial-Services-Sector-Supplement.pdf (accessed 27 September 2015).

Global Reporting Initiative Database [online] http://database.globalreporting.org/ (accessed 21 September 2015).

Haldane, A., Brennan, S. and Madouros V. (2010) 'What is the contribution of the financial sector: miracle or mirage?', in Turner et al. (Eds.): The Future of Finance: The LSE Report, London School of Economics and Political Science [online] http://www.voxeu.org/article/whatcontribution-financial-sector (accessed 24 September 2015).

Hicks, E.L. (1964) 'Materiality', Journal of Accounting Research, Autumn, Vol. 2, No. 2, pp.158-171.

Higgins, C. (2010) 'Is a responsive business also a responsible business?', Journal of Business Systems, Governance and Ethics, Vol. 5, No. 3, pp.23-33.

HSBC (2008) Sustainability Report [online] http://www.corporateregister.com/a10723/2622809Su-7396296R655332808K-Gl.pdf (accessed 21 September 2015).

HSBC (2009) Sustainability Report [online] http://www.corporateregister.com/a10723/3095610Su-6500760T6866536096S-Gl.pdf (accessed 21 September 2015).

HSBC (2011) Sustainability Report [online] http://www.corporateregister.com/a10723/4669812Su-11207520L4745263968F-Gl.pdf (accessed 21 September 2015).

HSBC (2012) Sustainability Report [online] http://www.corporateregister.com/a10723/5440313Su-15776870J7358767392S-Gl.pdf (accessed 21 September 2015).

HSBC [online] http://www.hsbc.com/about-hsbc?WT.ac=HGHQ_f1.1 (accessed 21 September 2015).

ICBC (2011) Sustainability Report [online] http://download.cib.com.cn/netbank/download/en/Sustainability/Report_2011_1.pdf (accessed 21 September 2015).

ICBC (2012) Sustainability Report [online] http://download.cib.com.cn/netbank/download/en/Sustainability/Report_2012.pdf (accessed 21 September 2015).

ICBC [online] http://www.icbc-ltd.com/icbcltd/en/ (accessed 21 September 2015).

International Integrated Reporting Council (2013) Consultation Draft of the International $<I R>$ Framework [online] http://integratedreporting.org/wp-content/uploads/2013/03/ConsultationDraft-of-the-InternationalIRFramework.pdf (accessed 24 September 2015).

Jones, P., Comfort, D. and Hillier, D. (2015) 'Materiality in corporate sustainability reporting within UK retailing', Journal of Public Affairs, published online in Wiley Online Library, DOI:10.1002/ pa.1570. 
KPMG (2013) Carrots \& Sticks - Sustainability Reporting Policies Worldwide - Today's Best Practice, Tomorrow's Trends [online]

http://www.ga-institute.com/fileadmin/user_upload/Reports/Carrots-and-Sticks.pdf (accessed 24 September 2015).

Mitsubishi UFJ (2011) UFJ Corporate Social Responsibility Report [online] http://static.globalreporting.org/report-pdfs/2011/119ad216af8b0aba662477fee3a02173.pdf (accessed 20 September 2015).

Mitsubishi UFJ Financial Group (MUFG) [online] http://www.mufg.jp/english/ (accessed 20 September 2015).

Mitsubishi UJF (2009) UFJ Corporate Social Responsibility Report [online] http://static.globalreporting.org/report-pdfs/2009/0003f08c0024fae09c41ba80373f8d73.pdf (accessed 18 September 2015).

Moir, L. and Kennerley, M. (2006) 'What to measure in the twenty-first century?', in Kakabadse, A. and Morsing, M. (Eds.): Corporate Social Responsibility: Reconciling Aspiration with Application, pp.81-93, Palgrave Macmillan, London.

Murninghan, M. (2013) Redefining Materiality II: Why It Matters, Who's Involved, and What It Means for Corporate Leaders and Boards [online] http://www.accountability.org/images/content/6/8/686/AA_Materiality_Report_Aug2013\%20 FINAL.pdf (accessed 20 September 2015).

Murray, A. (2008) Corporate Responsibility: A Critical Introduction, Oxford University Press, Oxford.

QSR International (2014) [online] http://www.qsrinternational.com/default.aspx (accessed 20 September 2015).

Rappaport, D. (1964) 'Materiality', Journal of Accountancy (Pre-1986), Vol. 117, No. 000004, p.42 [online] http://search.proquest.com/docview/198248201?accountid=174532 (accessed 20 September 2015).

Reich, B.R. (1998) 'The new meaning of corporate social responsibility', California Management Review, Vol. 40, No. 2, pp.8-17.

Rose, J., Beaver, W., Becker, S. and Sorter G. (1970) 'Toward an empirical measure of materiality', Journal of Accounting Research, Empirical Research in Accounting: Selected Studies, Vol. 8, pp.138-148 [online] http://doi.org/10.2307/2674700 (accessed 15 July 2015).

Securities Act of 1933, 210.1-02 Definitions of terms used in Regulation S-X [online] https://www.sec.gov/about/laws/sa33.pdf (accessed 20 September 2015).

Tschopp, D. and Huefner, R.J. (2015) 'Comparing the evolution of CSR reporting to that of financial reporting', Journal of Business Ethics, Vol. 127, No. 3, pp.565-577.

United Nations (1987) Our Common Future, Brundtland Report [online] http://www.channelingreality.com/Documents/Brundtland_Searchable.pdf (accessed 24 September 2015).

United Nations (2012) The Future we Want (Rio+20 Outcome Document) [online] http://sustainabledevelopment.un.org/futurewewant.html (accessed 20 September 2015).

Wheeler, D., Colbert, B. and Freeman, E. (2003) 'Focusing on value: reconciling corporate social responsibility, sustainability and stakeholder approach in a networked world', Journal of General Management, Vol. 28, No. 3, pp.1-28. 


\section{Appendix}

Table A1 Banks and links to their sustainability reports

\begin{tabular}{lccccc}
\hline Bank & 2008 & 2009 & 2010 & 2011 & 2012 \\
\hline Industrial and Commercial Bank of China (ICBC) & $\mathrm{V}^{1}$ & $\mathrm{~V}^{2}$ & $\mathrm{~V}^{3}$ & $\mathrm{~V}^{4}$ & $\mathrm{~V}^{5}$ \\
HSBC Holdings & $\mathrm{V}^{6}$ & $\mathrm{~V}^{7}$ & $\mathrm{~V}^{8}$ & $\mathrm{~V}^{9}$ & $\mathrm{~V}^{10}$ \\
Deutsche Bank & $\mathrm{X}$ & $\mathrm{V}^{11}$ & $\mathrm{~V}^{12}$ & $\mathrm{~V}^{13}$ & $\mathrm{~V}^{14}$ \\
Crédit Agricole Group & $\mathrm{X}$ & $\mathrm{X}$ & $\mathrm{X}$ & $\mathrm{X}$ & $\mathrm{X}$ \\
BNP Paribas & $\mathrm{V}^{15}$ & $\mathrm{~V}^{16}$ & $\mathrm{~V}^{17}$ & $\mathrm{~V}^{18}$ & $\mathrm{~V}^{19}$ \\
Mitsubishi UFJ Financial Group & $\mathrm{x}$ & $\mathrm{V}^{20}$ & $\mathrm{~V}^{21}$ & $\mathrm{~V}^{22}$ & $\mathrm{~V}^{23}$ \\
\hline
\end{tabular}

Source: ${ }^{1}$ http://download.cib.com.cn/netbank/download/cn/Sustainable Finance/Report_2008.pdf

${ }^{\overline{2}}$ http://download.cib.com.cn/netbank/download/en/Sustainability/ 2009_report.pdf

${ }^{3}$ http://download.cib.com.cn/netbank/download/en/Sustainability/ Report_2010_1.pdf

${ }^{4}$ http://download.cib.com.cn/netbank/download/en/Sustainability/ Report_2011_1.pdf

${ }^{5}$ http://download.cib.com.cn/netbank/download/en/Sustainability/ Report 2012.pdf

${ }^{6} \mathrm{http}: / /$ www.corporateregister.com/a10723/ 26228-09Su-7396296R655332808K-Gl.pdf ${ }^{7} \mathrm{http}: / /$ www.corporateregister.com/a10723/ 30956-10Su-6500760T6866536096S-Gl.pdf ${ }^{8}$ http://www.corporateregister.com/a10723/ 38609-11Su-7721800N11716016877N-Gl.pdf ${ }^{9} \mathrm{http}: / / \mathrm{www}$. corporateregister.com/a10723/ 46698-12Su-11207520L4745263968F-Gl.pdf

${ }^{10} \mathrm{http}: / / \mathrm{www}$. corporateregister.com/a10723/ 54403-13Su-15776870J7358767392S-Gl.pdf

${ }^{11} \mathrm{http}: / /$ www.corporateregister.com/a10723/ 30991-10Su-8274597R1050346972I-Gl.pdf

${ }^{12} \mathrm{http} / /$ www.corporateregister.com/ a10723/38747-11Su-7943135H1266174466I-Gl.pdf

${ }^{13} \mathrm{http}: / /$ www.corporateregister.com/a10723/ 45267-12Su-12810561C3564866784Q-Gl.pdf ${ }^{14} \mathrm{http}: / /$ www.corporateregister.com/a10723/ 53495-13Co-12196860R6367723830T-Gl.pdf ${ }^{15} \mathrm{http}$ ://www.corporateregister.com/a10723/bnp07-env-fr.pdf ${ }^{16} \mathrm{http} / / / \mathrm{www}$. corporateregister.com/ a10723/26772-09Su-5622120Y2166390240A-Gl.pdf ${ }^{17} \mathrm{http}: / / \mathrm{www}$. corporateregister.com/ a10723/32447-10Su-8338879P2034621582R-Gl.pdf ${ }^{18} \mathrm{http}: / / \mathrm{www}$. corporateregister.com/ a10723/39719-11Su-10525535A5395428960X-Gl.pdf

${ }^{19} \mathrm{http}: / /$ www.corporateregister.com/a10723/ 49753-12Co-12637262K20107774456U-Gl.pdf

${ }^{20} \mathrm{http}$ ://static.globalreporting.org/ report-pdfs/2008/9980b8dbdac2dbb1ffef808714ab62b6.pdf

${ }^{21} \mathrm{http}: / /$ www.corporateregister.com/a10723/ 35441-10Co-8612163U961337125S-Gl.pdf

${ }^{22} \mathrm{http}: / /$ static.globalreporting.org/ report-pdfs/2011/119ad216af8b0aba662477fee3a02173.pdf

${ }^{23}$ http://www.mufg.jp/english/csr/csrreport/2012/pdffile/all.pdf 